\title{
Wacana Penerapan Hybrid Learning oleh Kemendikbud
}

\author{
Faliqul Jannah Firdausi \\ SMA Negeri 15 Bandung \\ faliqul.firdausi@upi.edu
}

\begin{abstract}
Abstrak. Pandemi COVID-19 telah membuat banyak sektor perlu melakukan aksi cepat tanggap untuk mencegah penyebaran semakin luas. Salah satunya adalah pendidikan. Pemerintah di Indonesia telah membuat keputusan yang responsif dan cepat untuk menghadapi COVID-19. Setelah empat bulan berlalu, tahun ajaran baru di masa pandemi akan dimulai pada bulan Juli dan Kemendikbud memiliki rencana untuk menerapkan hybrid learning. Wacana tersebut memperoleh banyak respons dari masyarakat. Berdasarkan hal tersebut, artikel ini mendiskusikan tentang apa itu hybrid learning, bagaimana kelebihan dan kekurangannya, dan apa yang perlu disiapkan oleh pemerintah jika ingin menerapkannya di Indonesia.
\end{abstract}

Kata kunci: Kemendikbud, COVID-19, Hybrid Learning, Pendidikan di Indonesia, Siswa.

Wacana Kemendikbud untuk menerapkan hybrid learning menuai berbagai respons dari masyarakat. Hybrid learning merupakan pembelajaran dengan sistem daring yang dikombinasikan dengan pertemuan tatap muka untuk beberapa jam. Beberapa orang menganggap bahwa hybrid learning sama halnya dengan blended learning, yaitu penggunaan model pembelajaran yang merupakan kombinasi antara pembelajaran konvensional tatap muka dengan pembelajaran daring [1].

Doni Koesoema, pakar pendidikan karakter, menentang wacana tersebut karena menurut beliau, pembelajaran tatap muka tetap lebih efektif dan efisien [2]. Mengingat bahwa pendidikan tidak hanya tentang transfer ilmu, melainkan juga bagaimana siswa bersosialisasi dengan teman sebaya ataupun guru sehingga pembelajaran tatap muka juga mempengaruhi pembentukan karakter mereka. Kurangnya akses dan kemampuan dalam menggunakan sarana teknologi digital juga menjadi faktor mengapa wacana untuk menerapkan hybrid learning tersebut perlu dikaji ulang.

\section{Apa Kelebihan dari Hybrid Learning?}

Dalam pendidikan tinggi, hybrid learning menawarkan fleksibilitas dan akses untuk sumber pendidikan termasuk dosen, fakultas, dan materi kuliah. Mata kuliah yang fleksibel disampaikan dalam bentuk hybrid dalam mencapai keseimbangan antara pembelajaran tatap muka dan daring[1].

Salah satu syarat yang perlu dipenuhi sebuah institusi untuk menerapkan hybrid learning adalah mereka perlu memiliki sistem manajemen pembelajaran daring yang kuat yang mana mata kuliah dapat diberikan sepenuhnya melalui daring. Mahasiswa dengan kemampuan teknologi yang baik cenderung memiliki mata kuliah daring, karena hal tersebut memberikan mereka fleksibilitas dalam waktu dan tempat. Mahasiswa yang bekerja sambil kuliah ataupun tinggal jauh dari kampus juga mendapatkan manfaat dari kuliah online ini. Selain itu, mahasiswa atau siswa juga dapat mengulang materi yang ingin mereka pelajari kapanpun dan dimanapun dengan menggunakan hybrid learning[1].

\section{Apa Kekurangan dari Hybrid Learning?}

Banyak mahasiswa cenderung memilih pertemuan tatap muka sebagai model pembelajaran yang efektif karena terdapat interaksi langsung antara mahasiswa dan dosen mereka [1]. Pembelajaran daring mungkin memiliki kegunaannya sendiri, namun pembelajaran dengan tatap muka memiliki nilai tersendiri yang tidak bisa diabaikan. Mahasiswa dapat menciptakan kegiatan sosial interaktif dengan dosen mereka sebagaimana dengan teman sebaya mereka. 
Kampus juga tetap perlu menawarkan pertemuan tatap muka untuk beberapa mata kuliah dan tingkatan strata seperti doktoral dimana mahasiswa membutuhkan pertemuan secara fisik dengan pembimbing mereka agar memperoleh mentoring personal untuk penelitian mereka serta pemahaman akademis [1].

\section{Apa yang Sudah Dilakukan oleh Pemerintah dan Institusi Pendidikan?}

Kemendikbud, selaku wakil pemerintah dalam sektor pendidikan, telah membuat keputusan yang cepat tanggap dalam menghadapi pandemi COVID-19 ini. Dua minggu setelah ditemukan kasus positif pertama di Indonesia, Dinas Pendidikan memutuskan untuk menutup sekolah agar mengurangi kemungkinan terjadinya penyebaran virus tersebut di lingkungan pendidikan [3]. Siswa diminta untuk belajar dari rumah dan guru juga harus beradaptasi menggunakan teknologi untuk menyampaikan materi sekolah, meskipun ini terasa dipaksakan. Selain itu Kemendikbud juga menyediakan solusi layanan Belajar dari Rumah melalui TVRI untuk membantu siswa yang tidak memiliki sarana teknologi digital yang memadai [4]. Dana darurat dari BOS juga disalurkan untuk orang tua siswa yang terdampak COVID-19 [7]. Ujian Nasional tahun ini juga dibatalkan dan penyelenggaraan kelulusan diserahkan kepada sekolah berdasarkan hasil nilai rapot lima semester terakhir [5]. Sedangkan ujian masuk ke perguruan tinggi juga diundur [6].

Selain itu, baru-baru ini Kemendikbud juga membagikan panduan dalam penyelenggaraan pembelajaran pada tahun ajaran baru 2020/2021 di masa pandemi COVID-19. Prinsipnya adalah kesehatan dan keselamatan warga sekolah adalah hal yang diprioritaskan [7]. Daerah yang diperbolehkan untuk membuka sekolah kembali adalah daerah zona hijau dimana hanya ada 6\% di Indonesia. Kemendikbud juga memberikan ilustrasi bagaimana cara mengambil keputusan apakah sekolah dapat melakukan pembelajaran tatap muka atau tidak selama masa pandemi COVID-19.

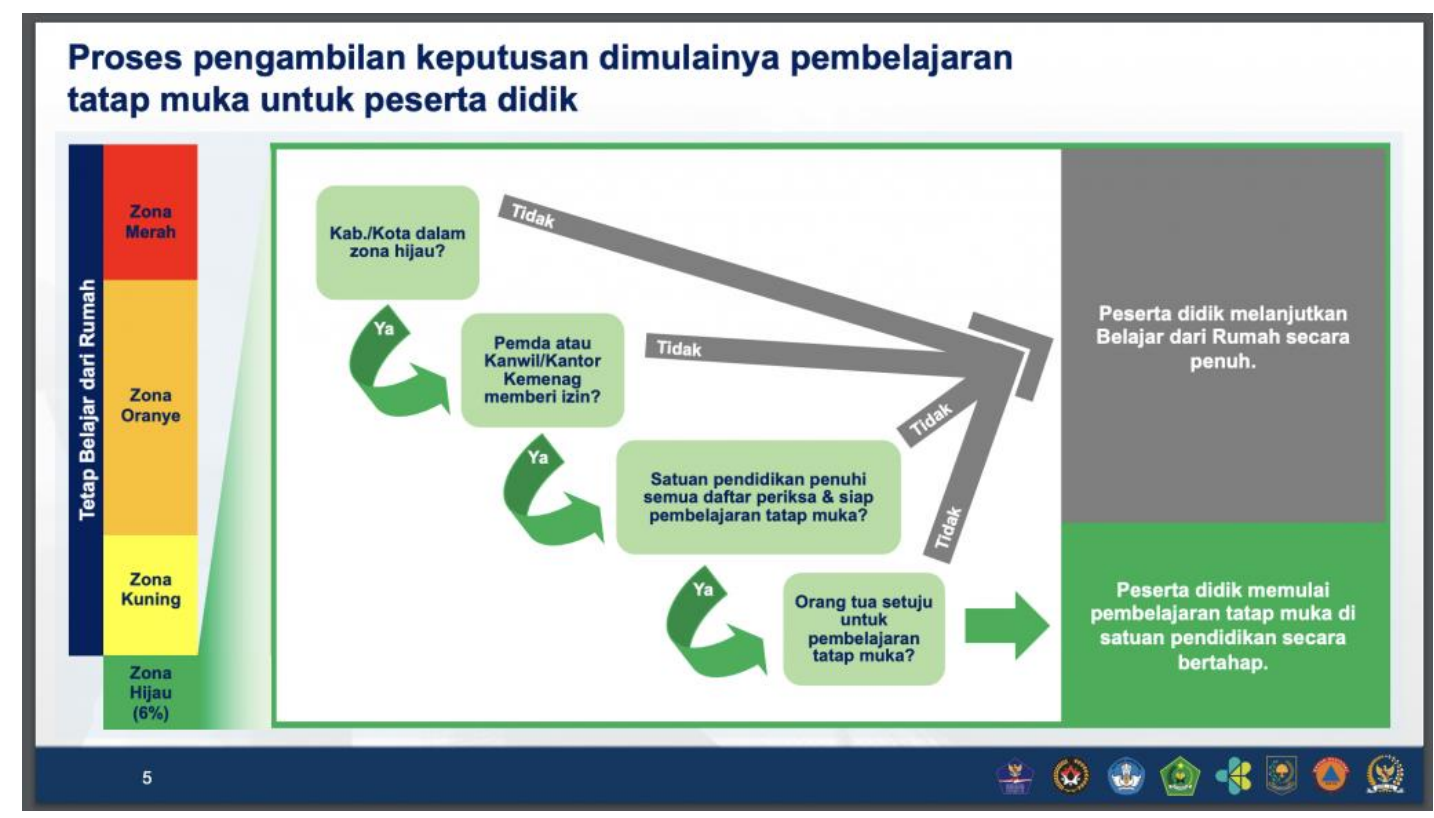

Gambar 1 Proses Pengambilan Keputusan Pembelajaran Tatap Muka untuk Peserta Didik

Hal yang menarik dari bagan tersebut adalah adanya persetujuan orang tua dalam pengambilan keputusan. Orang tua biasanya hanya dapat memberikan masukan, kritik, ataupun saran, namun tidak dilibatkan dalam pengambilan keputusan yang berdampak langsung keberlangsungan pembelajaran di sekolah. Selain itu, meskipun sekolah yang berada di zona hijau dapat dibuka kembali untuk peserta didik, akan tetapi terdapat tiga tahap dalam masa transisi yang perlu dilaksanakan dalam melaksanakan pembelajaran tatap muka di 
sekolah. Panduan tersebut juga menyediakan daftar periksa persiapan yang disajikan dengan mudah dipahami.

Kemendikbud terkesan responsif dalam menghadapi keluhan-keluhan yang disampaikan oleh masyarakat. Seperti kurangnya ketersediaan internet, keluarga yang terdampak COVID-19, permintaan untuk keringanan UKT, dan lain sebagainya. Akan tetapi, baru-baru ini Mendikbud, Nadiem Makarim, cukup menggemparkan masyarakat dalam wacana yang ia ajukan kepada DPR tentang penerapan hybrid learning [2].

Beberapa respons masyarakat yang kontra terhadap wacana tersebut memiliki concern terhadap kurangnya ketersediaan internet untuk menyeimbangi dalam proses penerapan hybrid learning tersebut. Selain itu pakar pendidikan karakter dan guru juga mempertimbangkan bahwa pertemuan tatap muka tetap lebih efektif untuk menguatkan karakter siswa [2].

\section{Mungkinkah Penerapan Hybrid Learning di Masa Pandemi COVID-19?}

Sangat mungkin. Akan tetapi sebenarnya ada hal yang rasanya terlewatkan dibahas oleh Kemendikbud serta dinas pendidikan. Yaitu, hilangnya semangat belajar atau rasa ingin belajar siswa sejak belajar dari rumah [8]. Memang, Kemendikbud menekankan untuk tidak menuntaskan materi belajar pada tahun ajaran 2019/2020 karena melihat kondisi psikis siswa sangat memungkinkan terganggu selama pandemi ini. Akan tetapi, apakah ada tindakan lanjutan setelah ini? Mengingat bahwa berdasarkan laporan OECD menyebutkan hanya 34\% siswa Indonesia yang memiliki komputer di rumah, belum lagi jika komputer tersebut harus berbagi dengan anggota keluarga lain yang sama-sama harus bekerja dari rumah [9]. Lebih dari itu, sebanyak 70\% dari siswa Indonesia tidak memiliki ruang belajar khusus di rumah mereka. Dengan ditutupnya sekolah, para siswa Indonesia sangat memungkinkan kehilangan semangat belajar selama di rumah karena mereka banyaknya tidak memiliki tempat khusus untuk belajar serta sarana belajar yang memadai. Sehingga, seyogyanya pada tahun ajaran baru Kemendikbud bertindak lanjut untuk melakukan remedial dalam mengulang atau mengejar materi sekolah yang belum tuntas pada semester genap 2019/2020 sebelum melanjutkan pembelajaran lanjutan pada tahun ajaran baru. Tidak lupa dengan layanan kesehatan jiwa yang perlu disediakan di sekolah untuk siswa.

Kembali ke hybrid learning.Perlu diingat bahwa hybrid learning bukan hanya pembelajaran secara daring. Namun ini merupakan kombinasi dari pembelajaran tatap muka dengan pembelajaran secara daring. Sehingga manfaat dari keduanya tetap bisa kita nikmati. Akan tetapi, kita perlu memperhatikan poin penting yang harus disiapkan sebelum menyelenggarakan sistem belajar hybrid. Salah satunya adalah institusi pendidikan yang akan melaksanakan hybrid learning tersebut baiknya memiliki sistem manajemen pembelajaran online yang kuat. Lebih dari itu, tenaga kependidikan, guru, dan siswa juga harus memiliki kemampuan teknologi digital yang baik dan sarana teknologi digital yang memadai di tempat mereka tinggal. Selain itu kecepatan internet juga perlu menjadi perhatian oleh pemerintah, khususnya Kominfo jika hybrid learning perlu diterapkan.

Jika hal-hal tersebut telah terpenuhi, pendidikan karakter perlu disusun ulang perencanaan, pelaksanaan, serta evaluasinya dalam penerapan hybrid learning. Perlu adanya diskusi antara para pemangku kebijakan di Kemendikbud dengan mengajak para guru, pakar pendidikan karakter, orang tua dengan latar belakang yang beragam agar penerapan hybrid learning dapat memberikan manfaat sesuai tujuannya yaitu memberikan fleksibilitas dan aksesbilitas, bukan malah menjadi beban masyarakat umum. 


\section{Referensi}

[1] Abdelrahman, N., \& Irby, B. J. (2016). Hybrid learning: Perspectives of Higher Education the Faculty. International Journal of Information Communication Technologies and Human Development (IJICTHD), $8(1)$, pp 1-25.

[2] Pramasta, D. B. (2020). Menteri Nadiem Wacanakan Belajar Jarak Jauh Permanen Setelah Pandemi Covid-19, Mungkinkah?. Tersedia di: www.kompas.com.

[3] Pratiwi, G. (2020). Sekolah di DKI Jakarta Libur Dua Pekan Sejak 16 Maret 2020. Tersedia di: www.pikiran-rakyat.com

[4] Kemdikbud. (2020). Ragam program tayangan "Belajar dari Rumah" di TVRI. Tersedia di: https://www.kemdikbud.go.id/main/blog/2020/04/ragam-tayangan-belajar-dari-rumah-di-tvri

[5] Kemendikbud. (2020). Surat Edaran No. 4 Tahun 2020 Pelaksanaan Kebijakaan Pendidikan dalam Masa Darurat Penyebaran COVID-19. Jakarta: Kemendikbud.

[6] Kasih, A.P. (2020). Info Terbaru LTMPT: UTBK 2020 Ditunda terkait Wabah Corona. Tersedia di: www.kompas.com

[7] Kemendikbud. (2020). Panduan: Penyelenggaraan Pembelajaran Pada Tahun Ajaran dan Tahun Akademik Baru di Masa Pandemi Corona Virus Disease (COVID-19). Tersedia di: www.bersamahadapicorona.kemdikbud.go.id

[8] OECD. (2020). Coronavirus special edition: back to school. OECD Publishing. Tersedia di: http://www.oecd.org/education/ceri/Spotlight-21-Coronavirus-special-edition-Back-to-school.pdf

[9] OECD. (2020). A framework to guide education to response the COVID-19 Pandemic 2020. Tersedia di: https://oecd-ilibrary.org/ 